\title{
Correlation and Path Coefficient Analysis among Yield Component Traits of Ethiopian Korerima [Aframomum Corrorima (Braun) P. C. M. Jansen] Genotypes at Tepi, Ethiopia
}

\author{
Hassen Seid ${ }^{1} \quad$ Wassu Mohammed ${ }^{2}$ Abebe Atilaw ${ }^{3}$ \\ 1. Tepi National Spices Research Center, P.O.Box 34, Tepi, Ethiopia \\ 2 .Department of Plant Science, College of Agriculture and Environmental Sciences, Haramaya University, \\ Haramaya \\ 3 .Ethiopian Institute of Agricultural Research, Addis Ababa, Ethiopia
}

\begin{abstract}
An experiment was conducted in research fields to study Phenotypic and genotypic correlation co-efficient of quantitative characters and character association of korerima. Twenty-five korerima germplasm of diverse sources were used to assess the character association and contribution of characters towards capsule/seed yield. Path coefficient analyses were carried out for selected genotypes and to find out the direct and indirect effect of component characters on capsule/seed yield. Analysis of phenotypic and genotypic correlation co-efficient of quantitative characters and partitioning of genotypic correlation to pure seed revealed positive and significant correlation both at genotypic and phenotypic levels with number of capsule bearing suckers per plant, number of capsules per plant, dry capsules weight, number of seeds per capsule, total seeds weight per capsule, dry capsule yield per plot and dry capsule yield ha ${ }^{-1}$. Number of seeds per capsule, total seed weight per plot, dry capsule yield per plot and dry capsule yield had high and positive direct effects on pure seed yield, however, number of capsule bearing sackers per plant, dry capsule weight and number of capsule per plant had negative direct effects on pure seed yield at genotypic level. The result indicated that the positive and significant correlation of number of capsule bearing suckers per plant, dry capsule weight, total seed weight per plot, dry capsule yield per plot and dry capsule yield $\mathrm{kg} \mathrm{ha}^{-1}$ with pure seed yield per plot were due to the high direct effect of the characters. Data of this study might be useful for quantitative assessment of the variation in yield and yield components, their interrelationship, and direct and indirect effects of different characters on seed yield of korerima.
\end{abstract}

Keywords: Correlation, Direct Effect, Indirect Effect, Path Coefficien, Aframomum corrorima, Korerima

DOI: $10.7176 / \mathrm{JBAH} / 9-9-06$

Publication date:May $31^{\text {st }} 2019$

\section{INTRODUCTION}

Korarima [Aframomum corrorima (Braun) P.C.M. Jansen] is herbaceous, perennial and aromatic species classified in the monocotyledonous family Zingiberaceae and belongs to the genus Aframomum. The chromosomes of korarima were observed to be small in size and their diploid number was found to be $2 n=$ $2 \mathrm{x}=48$ (Surawit and Wondyifraw, 2013). The plant consists of an underground rhizome, a pseudo stem, and several broad leaves and morphologically it resembles Elettaria species. Mature korarima plant can reach a height of 1-2 m. It sets seed after 3-5 years of planting depending on the planting materials used and it continue to bear seeds for a number of decades (Eyob, 2009).

Seeds of korerima are mainly used as a spice and condiment in different traditional Ethiopian dishes and they serve as a source of income to the growers as they fetch high prices both at local and export markets. In addition, pods, leaves, rhizomes and/or flowers of korerima are commonly used in traditional medicine and as a spice and condiment in different parts of the country, including Southern Ethiopia (Eyob et al., 2008).

Assessment of genetic variability in crops has a strong impact on plant breeding and conservation of genetic resources. It is particularly useful in crops not well studied. The knowledge of the crop nature, extent and distribution of genetic variation is crucial for successful selection of individual genotypes to be used as parents in hybridization program or to develop as variety. The number of populations necessary to conserve genetic diversity within a species depends on the measure of diversity and its pattern of partition within and among populations (Kassahun, 2006). Very recently, by Tepi National Spices Research Centre large numbers of korerima genotypes were collected from major growing regions of Ethiopia to assess the genetic variations among genotypes and thereby to develop varieties.

Measurement of correlation coefficient helps identify the relative contribution of component characters towards yield (Panse, 1957). Moreover, the correlation between grain yield and a component character may sometimes be misleading due to an over estimation or underestimation for its association with other characters. Thus, yield components have influence on ultimate yield both directly and indirectly (Tukey, 1954). Splitting of total correlation into direct and indirect effects, therefore, would provide a more meaningful interpretation of such association. Path coefficient, which is a standard partial regression coefficient, specifies the cause and 
effect relationship and measures the relative importance of each variable (Wright, 1921). Therefore, correlation in combination with path coefficient analysis will be an important tool to find out the association and quantify the direct and indirect influence of one character upon another (Dewey and Lu, 1959). Considering the above facts the present study has been undertaken with the following objectives:

$>$ to assess the character association and contribution of characters towards grain yield of selected genotypes, and

$>$ to identify the direct and indirect effect of component characters on grain yield with the help of path coefficient analysis.

\section{MATERIALS AND METHODS \\ Description of the Study Area}

The experiment was conducted at Tepi National Spices Research Center (TNSRC). Tepi National Spices Research Center is located in South Nation and Nationalities People (SNNP) Regional State at an elevation of 1200 meter above sea level. The research center is situated at Latitude of $7010^{\prime} 54.5^{\prime \prime} \mathrm{N}$ and with a Longitude of $35025^{\prime}$ '04.3-28.2' E in the warm humid low land area of south western Ethiopia. The mean annual rain fall recorded at the station is $1559 \mathrm{~mm}$ and the average annual minimum and maximum temperatures were $15.5^{\circ} \mathrm{C}$ and $29.7^{\circ} \mathrm{C}$, respectively (TNSRC, 2015).

\section{Experimental materials and design}

The genetic variability study was conducted using 25 Korerima genotypes that were collected from Kaffa, Bench-Maji, Gamo Gofa, Sheka, Sidamo, Wollega, Illubabor, Bale, Jimma, South Omo and north western of Ethiopia growing regions for variety development and the collections were maintained at Tepi National Spices Research Center. The descriptions of the genotypes were presented in (Table 1).

The experiment was superimposed on those which were planted in a simple lattice design with two replications and five genotypes per incomplete block. Twenty plants per plot were planted with a spacing of $2 \mathrm{~m}$ both between rows and plants. The genotypes were grown under natural forest shade trees. Each genotype was assigned in one plot in each replication where each plot was with width and length of $8 \times 10 \mathrm{~m}$. Plants grown at two rows left the two plants grown at most end of each row were considered for data collection. The data collected from the field were analyzed as per simple lattice design..

\section{Experimental procedure and data collection}

Data from the experimental field was collected on sample plants and net plot basis. For this purpose, ten red ripe capsules were collected from ten randomly taken plants from net plot for each genotype and replication. Fresh and dried capsules characters were measured and the mean value was registered for analysis. The seeds were extracted after drying of the sample capsules and seeds physical quality parameters was measured. All the data collected for capsules, seed physical quality and capsule yield $\left(\mathrm{kg} \mathrm{ha}^{-1}\right)$ from the experimental field was analyzed using the simple lattice design where the genotypes were maintained. 
Table 1 List of the 25 korerima genotypes.

\begin{tabular}{|c|c|c|c|c|c|}
\hline No. & Genotypes code & Region & Zone & Wereda & Altitude \\
\hline 1 & $053 / 03$ & SNNPR & South omo & Kemba & 1850 \\
\hline 2 & $046 / 03$ & Oromiya & Illubabor & Algea & 1500 \\
\hline 3 & $114 / 03$ & Oromia & Illubabor & Sombo & 2229 \\
\hline 4 & $029 / 84$ & Oromia & Wollega & Gimbi & 1930 \\
\hline 5 & 038/01 & SNNPR & Sidamo & Arero & 2829 \\
\hline 6 & $045 / 03$ & SNNPR & Gamogofa & Damot & 2121 \\
\hline 7 & $021 / 00$ & SNNPR & Benchi maji & Bebeka & 1285 \\
\hline 8 & $015 / 03$ & Oromiya & Illubabor & Smbo & 2229 \\
\hline 9 & Jimma local & Oromia & Jimma & Jimma & 1580 \\
\hline 10 & $686 / 87$ & Amhara & Gojam & Metekel & 1525 \\
\hline 11 & $001 / 00$ & Oromia & Bale & Genale & 1000 \\
\hline 12 & 093/00 & Amhara & Gojam & Debre markos & 2446 \\
\hline 13 & BM31/03 & SNNPR & Kafa & Chena & 1500 \\
\hline 14 & $028 / 84$ & Oromia & Wollega & Arjo & 1800 \\
\hline 15 & $701 / 87$ & SNNPR & Kafa & Decha & 2500 \\
\hline 16 & $68 / 87$ & Amhara & Gojam & Agew midir & 1500 \\
\hline 17 & $25 / 03$ & Oromia & Illubabor & Metu & 1605 \\
\hline 18 & BM34/03 & SNNPR & Kafa & Chena & 1972 \\
\hline 19 & $059 / 03$ & Oromia & Wollega & Nekemte & 2088 \\
\hline 20 & $018 / 00$ & SNNPR & Kafa & Yeki & 1097 \\
\hline 21 & $016 / 84$ & Oromia & Illubabor & Sombo & 2229 \\
\hline 22 & 009/00 & Amhara & Gojam & Metekel & 1525 \\
\hline 23 & $105 / 03$ & Oromia & Illubabor & Yayu & 1387 \\
\hline 24 & $010 / 00$ & SNNPR & Kafa & Chena & 1972 \\
\hline 25 & $011 / 00$ & SNNPR & Sidamo & Sidama & 2759 \\
\hline
\end{tabular}

Source: Tepi National Spice Research Centre

\section{Data Collection:}

The following data were collected from the experimental field both per plot and per plant basis:

Plant height (cm): Plant height was measured from ten randomly taken plants in centimeters from ground level to the plant tip and the average measurement was taken.

Number of sucker per plant: Number of sucker produced from ten randomly taken plants in each net plot was counted and the average measurement was taken.

Number of capsules bearing sucker per plant: Number of capsule bearing suckers produced from ten randomly taken plants in each net plot was counted and the average measurement was taken

Internodes length (cm):It was measured in centimeters the length that was found between two consecutive nodes at physiological maturity using ten randomly taken plants.

Number of leaves per stem: Number of leaves produced from ten randomly taken plants in each net plot was counted and the average measurement was taken.

Leaf area $\left(\mathbf{c m}^{2}\right)$ : Leaf area was taken using $(\mathrm{cm})$ from ten randomly taken plants in each net plot and the average measurement was taken.

Number of capsules per plant: Number of capsules produced from ten randomly taken plants in each net plot was counted and the average measurement was taken.

Fresh capsules diameter (cm): Ten capsules was randomly taken from capsules collected from ten plants and each capsule girth was measured to the widest portion using caliper and the average of the ten capsules measurement was taken.

Fresh capsules length (cm): It was measured from ten capsules that girth was measured. Each capsule length was measured from the top to the lower end of capsule and the average of 10 capsules was calculated to register fresh capsules length in $(\mathrm{cm})$.

Dry capsules diameter $(\mathbf{c m})$ : Ten capsules was randomly taken from capsules collected from five plants and dried, each dried capsule girth was measured to the widest portion using caliper and the average of the ten capsules measurement was taken.

Dry capsules length (cm): It was measured from 10 dried capsules that girth was measured. Each dried capsule length was measured from the top to the lower end of capsule and the average of 10 capsules was calculated to register dried capsules length in $(\mathrm{cm})$.

Fresh capsules weight (g): It was calculated from capsules collected from ten randomly taken plants in each net plot by weighed the total capsules collected and divided by the number of capsules. 
Dry capsules weight of (g): It was calculated from capsules collected from ten randomly taken plants after drying, weighed and divided by the total number of capsules.

Dried capsules yield (kg per plot): All red ripe capsules produced by the plants in net plot were harvested, dried under open sun, weighed and calculated the dried capsule yield (kg per plot basis).

Dried capsules yield $\left(\mathbf{k g ~ h a}^{-1}\right)$ : All red ripe capsules produced by the plants in net plot was harvested, dried under open sun, weighed and calculated the dried capsule yield (kg ha-1 basis).

Number of seeds per capsule: Number of seed(s) per capsule was recorded by taking the mean number of seeds obtained from ten sampled capsules

1000 seeds weight (g): It was taken by weighing 1000 seeds drawn randomly from the yield obtained from each experimental plot.

Total seeds weight per capsule (g): It was registered the pure seed obtained from ten capsules weight in gram and taking the mean value.

Pure seed yield (kg per plot): It was calculated from pure seeds weight per capsule considering the plant population per plot and number of capsules collected per plant.

Statistical Analysis:

Data collected were subjected to analysis of variance for the design and treatment arrangement as the procedure indicated by Gomez and Gomez (1984) using Statistical Analysis System (SAS, 2001) computer software. Where significant differences were detected, the means separation was carried out using the least significant differences (LSD) at 0.05 level of probability.

Here are the formulas used for this investigation and results are published by Karim et al. (2007):

\section{Correlation coefficient (r):}

Estimation of genotypic and phenotypic correlation coefficients were done based on the procedure of Dabholkar (1992).

Genotypic Correlation Coefficient $\left(\mathrm{r}_{\mathrm{g}}\right)=(\operatorname{Covg}(\mathrm{xy})) /(\sigma \mathrm{g}(\mathrm{x}) * \sigma \mathrm{g}(\mathrm{y})$
Phenotypic Correlation Coefficient $\mathrm{t}\left(\mathrm{r}_{\mathrm{ph}}\right)=\frac{\operatorname{COVph}(\mathrm{xy})}{\sigma \mathrm{ph}(\mathrm{x}) * \sigma \mathrm{ph}(\mathrm{y})}$

Where, COVg (xy) and COVph (xy) were the genotypic and phenotypic covariance of two variables (X and Y), respectively. $\sigma \mathrm{g}(\mathrm{x})$ and $\sigma \mathrm{g}(\mathrm{y})$ were the genotypic standard deviations for variables $\mathrm{X}$ and $\mathrm{Y}$ respectively. $\sigma p h$ (x) and $\sigma \mathrm{ph}(\mathrm{y})$ were the phenotypic standard deviations of variables $\mathrm{X}$ and $\mathrm{Y}$, respectively. The calculated phenotypic correlation value was tested for its significance using t-test: $\mathrm{t}=\mathrm{rph} / \mathrm{SE}$ ( $\mathrm{rph}$ )

Where, $\mathrm{rph}=$ Phenotypic correlation; SE $(\mathrm{rph})=$ Standard error of phenotypic correlation obtained using the following formula (Sharma, 1998).

$\mathrm{SE}(\mathrm{rph})=\sqrt{\frac{1-\mathrm{r} 2 \mathrm{ph}}{\mathrm{n}-2}}$

Where, $\mathrm{n}$ is the number of genotypes tested, $\mathrm{r}^{2} \mathrm{ph}$ is phenotypic correlation coefficient.

The coefficients of correlations at genotypic levels were tested for their significance by the formula described by Robertson, (1959) as indicated below: $\mathrm{t}=$ rgxy/SErgxy

The calculated " $\mathrm{t}$ " value was compared with the tabulated " $\mathrm{t}$ " value at (n-2) degree of freedom at 5\% level of significance. Where, $\mathrm{n}$ is number of genotypes.

$\begin{aligned} & \text { SErgxy } \\ & \text { Where, } \\ & h^{2} y\end{aligned}=\sqrt{\frac{1-\mathrm{r} 2 \text { gxy }}{\mathbf{h} 2 \mathrm{x}} \cdot \mathbf{h} 2 \mathrm{y}} \begin{aligned} & \mathrm{h}^{2} \mathrm{x}=\text { Heritability of character } \mathrm{x} \\ & \text { Heritability of character } \mathrm{y}\end{aligned}$

Path coefficient analysis

The path coefficient analysis was done using the formula of Dewey and Lu (1959)

rij $=$ Pij + Erik Pkj

Where, rij is association between the independent variable (i) and dependent variable ( $\mathrm{j}$ ) as measured by correlation coefficient; Pij was component of direct effect of the independent variable (i) on the dependent variable (j) as measured by path coefficient; and Erik Pkj was summation of components of indirect effects of a given independent variable (i) on a given dependent variable (j) via all other independent variables. The residual factor $\left(\mathrm{P}^{2} \mathrm{R}\right)$ was estimated as described in Dewey and $\mathrm{Lu}(1959): 1=\mathrm{P}^{2} \mathrm{R}+\Sigma \mathrm{Pij}$ rij

Capsule yield $\mathrm{kg} \mathrm{ha}^{-1}$ was used as dependent characters for path coefficient analysis and other characters were used as independent variables as required.

\section{RESULTS AND DISCUSSION}

\section{Genotypic and Phenotypic Correlation Coefficients:}

Genotypic and phenotypic correlation estimates between the different characters are presented in Table 2. The results are presented and discussed in to three categories viz. correlation coefficient of pure seed with other 
characters, correlation coefficient of dry capsule yield with other characters and correlation coefficients among other characters. Yield is a complex character associated with many characters. Therefore, estimates of correlation between yield and other characters as well as among other characters is generating important information on which the selection of genotypes based in breeding programs. Correlation coefficient measures the mutual relationship between various plant characters and determines the component characters on which selection can be based for the improvement in yield as an associated complex characters (Korikanthimath, et al., 2000).

\section{Correlation coefficient of pure seed yield with other characters}

Pure seed yield per plot showed positive and significant correlation both at genotypic and phenotypic levels with number of capsule bearing suckers per plant, number of capsules per plant, dry capsules weight, number of seeds per capsule, total seeds weight per capsule, dry capsule yield per plot and dry capsule yield ha-1. In addition, pure seed yield had positive and significant phenotypic correlation with dry capsules length (Table 2). This suggested that the selection of genotypes for high mean values for these characters is the simultaneous selection of genotypes for high seed yield.

The results of present investigation is in confirmation with the results of Korikanthimath et al. (2000) that number of capsule per plant and dry capsules weight showed positive and high significant correlation with seed yield in cardamom.

\section{Correlation coefficient of dry capsule yield with other characters}

Dry capsule yield $\mathrm{kg} \mathrm{ha}^{-1}$ showed positive and significant correlation both at genotypic and phenotypic levels with number of capsule bearing suckers per plant, number of capsules per plant, dry capsule weight, total seed weight per capsule and dry capsule yield per plot. In addition, dry capsule yield $\mathrm{kg} \mathrm{ha}^{-1}$ showed positive and significant phenotypic correlation with dry capsules length and number of seed per capsule (Table 2).

This positive and significant association of pairs of characters shows the possibility of correlated response to selection is high. Therefore, any improvement of these characters would result in a considerable increment on dry capsule yield $\mathrm{kg} \mathrm{ha}^{-1}$. This finding is in close agreement with Korikanthimath et al. (2000) in cardamom.

\section{Correlations among other characters}

Plant height showed positive and highly significant genotypic and phenotypic association with internodes length, number of leaf per sucker, leaf area, dry capsule length and dry capsule diameter (Table 2). The result indicated that the higher chance of improving these characters simultaneously by selection of genotypes with high mean values. Number of capsule per plant showed positive and significant phenotypic association with number of capsule bearing suckers per plant and dry capsule weight. Dry capsule weight showed positive and significant phenotypic association with internodes length and dry capsule length.

The result indicated higher chance of improving these characters simultaneously by selection of genotypes with high mean values. The current findings is in close agreement with the results reported by Korikanthimath et al. (2000) positive and significant association was registered with dry capsule length and internodes length in cardamom.

Table 2. Estimates of correlation coefficients at phenotypic (above diagonal) and genotypic (below diagonal) levels of different characters in various korerima genotypes grown at Tepi

\begin{tabular}{|c|c|c|c|c|c|c|c|c|c|}
\hline Characters & $\begin{array}{r}\text { Plant } \\
\text { Height } \\
(\mathrm{cm})\end{array}$ & $\begin{array}{r}\text { No. of } \\
\text { capsule } \\
\text { bearing } \\
\text { sucker } \\
\text { / plant }\end{array}$ & $\begin{array}{r}\text { Internodes } \\
\text { length }\end{array}$ & $\begin{array}{l}\text { No. of } \\
\text { leaves } \\
\text { /plant }\end{array}$ & $\begin{array}{r}\text { Leaf } \\
\text { area } \\
\left(\mathrm{cm}^{2}\right)\end{array}$ & $\begin{array}{r}\text { No. of } \\
\text { capsule/ } \\
\text { plant }\end{array}$ & $\begin{array}{r}\text { Fresh } \\
\text { capsule } \\
\text { diameter } \\
(\mathrm{cm})\end{array}$ & $\begin{array}{r}\text { Fresh } \\
\text { capsule } \\
\text { length } \\
(\mathrm{cm})\end{array}$ & $\begin{array}{r}\text { Fresh } \\
\text { capsule } \\
\text { weight } \\
(\mathrm{g})\end{array}$ \\
\hline Plant Height $(\mathrm{cm})$ & & 0.063 & $0.638 * *$ & $\begin{array}{r}0.59 * \\
*\end{array}$ & $0.63 * *$ & 0.261 & 0.039 & -0.005 & -0.001 \\
\hline $\begin{array}{l}\text { No. of capsule bearing } \\
\text { Sucker/ plant }\end{array}$ & 0.035 & & 0.102 & -0.357 & -0.376 & 0.324 & 0.033 & 0.241 & 0.074 \\
\hline Internodes length & $0.496^{*}$ & 0.087 & & 0.171 & 0.381 & 0.099 & 0.170 & -0.308 & -0.030 \\
\hline No. of leaves/ plant & $0.530 * *$ & -0.090 & 0.089 & & $0.58 * *$ & 0.016 & -0.090 & -0.155 & -0.094 \\
\hline Leaf area $\left(\mathrm{cm}^{2}\right)$ & $0.464 *$ & -0.165 & 0.284 & 0.290 & & -0.10 & 0.237 & -0.303 & 0.078 \\
\hline No.of capsule/ plant & 0.173 & 0.330 & 0.048 & 0.158 & -0.053 & & -0.053 & 0.254 & 0.113 \\
\hline Fresh capsule diameter $(\mathrm{cm})$ & 0.076 & -0.003 & -0.013 & 0.168 & 0.295 & -0.220 & & -0.227 & 0.171 \\
\hline Fresh capsule length $(\mathrm{cm})$ & 0.032 & 0.133 & -0.026 & -0.280 & -0.201 & 0.115 & 0.071 & & 0.139 \\
\hline Fresh capsule weight (g) & -0.056 & 0.085 & -0.157 & 0.032 & 0.091 & -0.055 & 0.189 & 0.302 & \\
\hline Dry capsule diameter $(\mathrm{cm})$ & 0.128 & -0.005 & 0.074 & -0.106 & 0.265 & -0.231 & $0.492 *$ & -0.091 & 0.063 \\
\hline Dry capsule length $(\mathrm{cm})$ & 0.328 & 0.081 & 0.193 & 0.240 & 0.167 & 0.260 & -0.086 & -0.085 & 0.008 \\
\hline Dry capsule weight (g) & 0.356 & 0.126 & $0.412 *$ & 0.032 & 0.151 & 0.307 & -0.124 & 0.047 & -0.035 \\
\hline No. of seed/ capsule & -0.027 & 0.149 & -0.091 & -0.195 & 0.047 & 0.134 & 0.096 & 0.124 & 0.318 \\
\hline Total seed weight/ capsule (g) & 0.264 & -0.016 & 0.306 & 0.071 & 0.106 & 0.032 & -0.152 & -0.083 & -0.142 \\
\hline Seed yield ( $\mathrm{kg} / \mathrm{plot})$ & 0.267 & $0.57 * *$ & 0.240 & 0.083 & 0.027 & $0.640 * *$ & -0.181 & 0.037 & -0.097 \\
\hline
\end{tabular}




\begin{tabular}{|c|c|c|c|c|c|c|c|c|c|}
\hline Characters & $\begin{array}{r}\text { Plant } \\
\text { Height } \\
(\mathrm{cm})\end{array}$ & $\begin{array}{r}\text { No. of } \\
\text { capsule } \\
\text { bearing } \\
\text { sucker } \\
\text { / plant }\end{array}$ & $\begin{array}{r}\text { Internodes } \\
\text { length }\end{array}$ & $\begin{array}{l}\text { No. of } \\
\text { leaves } \\
\text { /plant }\end{array}$ & $\begin{array}{r}\text { Leaf } \\
\text { area } \\
\left(\mathrm{cm}^{2}\right)\end{array}$ & $\begin{array}{r}\text { No. of } \\
\text { capsule/ } \\
\text { plant }\end{array}$ & $\begin{array}{r}\text { Fresh } \\
\text { capsule } \\
\text { diameter } \\
(\mathrm{cm})\end{array}$ & $\begin{array}{r}\text { Fresh } \\
\text { capsule } \\
\text { length } \\
(\mathrm{cm})\end{array}$ & $\begin{array}{r}\text { Fresh } \\
\text { capsule } \\
\text { weight } \\
\text { (g) }\end{array}$ \\
\hline Dry capsule yield (kg/plot) & 0.345 & $0.54^{* *}$ & 0.309 & 0.018 & 0.134 & $0.535^{* *}$ & -0.149 & 0.056 & -0.054 \\
\hline Dry capsule yield $\left(\mathrm{kg} \mathrm{ha}^{-1}\right)$ & 0.395 & $0.60 * *$ & 0.332 & 0.036 & 0.010 & $0.642 * *$ & -0.150 & 0.123 & -0.017 \\
\hline Plant Height $(\mathrm{cm})$ & 0.051 & $0.397 *$ & 0.361 & -0.176 & & 0.370 & 0.296 & $0.416^{*}$ & 0.382 \\
\hline $\begin{array}{l}\text { No. of capsule } \\
\text { bearing sucker/ plant }\end{array}$ & 0.164 & 0.128 & 0.231 & 0.368 & & 0.151 & $0.628 * *$ & $0.588 * *$ & $0.654 * *$ \\
\hline Internodes length & 0.166 & $0.425^{*}$ & $0.480 *$ & -0.188 & & $.511 * *$ & 0.273 & $0.396^{*}$ & 0.356 \\
\hline No. of leaves/ plant & -0.087 & 0.280 & -0.021 & -0.264 & & 0.127 & -0.065 & -0.127 & -0.158 \\
\hline Leaf area $\left(\mathrm{cm}^{2}\right)$ & 0.173 & 0.137 & 0.128 & -0.159 & & 0.044 & -0.043 & 0.095 & -0.075 \\
\hline No. of capsule/ plant & -0.156 & 0.377 & $0.535 * *$ & 0.285 & & 0.146 & $0.674 * *$ & $0.572 * *$ & $0.720 * *$ \\
\hline Fresh capsule diameter $(\mathrm{cm})$ & $0.549 * *$ & -0.121 & -0.152 & 0.077 & & -0.134 & -0.102 & -0.130 & -0.094 \\
\hline Fresh capsule length $(\mathrm{cm})$ & $-0.437 *$ & -0.176 & -0.017 & 0.067 & & -0.064 & 0.117 & 0.043 & 0.144 \\
\hline Fresh capsule weight (g) & -0.304 & $-0.453^{*}$ & -0.079 & -0.003 & & -0.249 & -0.024 & -0.116 & 0.020 \\
\hline Dry capsule diameter $(\mathrm{cm})$ & & 0.003 & 0.083 & 0.277 & & 0.131 & 0.146 & 0.219 & 0.078 \\
\hline Dry capsule length $(\mathrm{cm})$ & -0.044 & & $0.456^{*}$ & 0.054 & & $0.436^{*}$ & $0.433 *$ & $0.441 *$ & $0.420 *$ \\
\hline Dry capsule weight $(\mathrm{g})$ & 0.213 & 0.273 & & 0.301 & & $664 * *$ & $0.754 * *$ & $0.788 * *$ & $0.854^{* *}$ \\
\hline No. of seed/ capsule & $0.467 *$ & 0.206 & 0.304 & & & 0.240 & $0.507 * *$ & $0.422 *$ & $0.396 *$ \\
\hline Total seed weight/capsule (g) & 0.278 & 0.255 & $0.679 * *$ & 0.190 & & & $0.674 * *$ & $0.524 * *$ & $0.497 *$ \\
\hline Seed yield ( $\mathrm{kg} /$ plot) & 0.115 & 0.277 & $0.696 * *$ & $0.398^{*}$ & & $.559 * *$ & & $0.891 * *$ & $0.908 * *$ \\
\hline Dry capsule yield (kg/ plot) & 0.022 & 0.281 & $0.723 * *$ & 0.272 & & $0.483 *$ & $0.896 * *$ & & $0.899 * *$ \\
\hline Dry capsule yield $\left(\mathrm{kg} \mathrm{ha}^{-1}\right)$ & 0.058 & 0.278 & $0.814 * *$ & 0.269 & & $0.441 *$ & $0.902 * *$ & $0.882 * *$ & \\
\hline
\end{tabular}

$*$ and $* *$, significant at $\mathrm{P}<0.05$ and $\mathrm{P}<0.01$ level (for $\mathrm{r}>0.396$ and $\mathrm{r}>0.505$ ) respectively.

\section{Path Coefficient Analysis}

Genotypic path analysis of pure seed yield with other characters:

The genotypic direct and indirect effect of different characters on pure seed yield per plot is presented in Table 3 . Number of seeds per capsule, total seed weight per plot, dry capsule yield per plot and dry capsule yield had high and positive direct effects on pure seed yield, however, number of capsule bearing sackers per plant, dry capsule weight and number of capsule per plant had negative direct effects on pure seed yield at genotypic level. The result indicated that the positive and significant correlation of number of capsule bearing sackers per plant, dry capsule weight, total seed weight per plot, dry capsule yield per plot and dry capsule yield $\mathrm{kg} \mathrm{ha}^{-1}$ with pure seed yield per plot were due to the high direct effect of the characters. But the positive and significant genotypic correlation of number of capsule bearing suckers per plant, dry capsule weight and number of capsule per plant with pure seed yield per plot were due to the high and positive indirect effects of other characters via this characters. For instance the positive and significant genotypic correlation of number of capsule per plant with pure seed yield per plot was due to the positive and high indirect effect of this character via dry capsule yield $\mathrm{kg}$ $\mathrm{ha}^{-1}$ and dry capsule yield per plot. The current finding is in agreement with the finding of Korikanthimath et al. (2000) that high and positive direct effects of capsule bearing tiller, dry capsule weight, and number of seed per capsule on pure seed yield of cardamom.

Genotypic path analysis residual value was 0.052 . This indicated that $94.8 \%$ of the variability in seed yield was explained by the component factors/characters included in genotypic path analyses. This suggested that the choice of seed yield attributing characters in the study was quite good.

Table 3. Genotypic direct effects (bold and diagonal) and indirect effects (off-diagonal) of different characters on seed yield in various korerima genotypes evaluated at Tepi

\begin{tabular}{|c|c|c|c|c|c|c|c|c|}
\hline Characters & $\begin{array}{r}\text { No. of } \\
\text { capsule } \\
\text { bearing } \\
\text { sucker } \\
\text { /plant }\end{array}$ & $\begin{array}{c}\text { No. of } \\
\text { capsule/ } \\
\text { plant }\end{array}$ & $\begin{array}{r}\text { Dry } \\
\text { capsule } \\
\text { weight }(\mathrm{g})\end{array}$ & $\begin{array}{l}\text { No. of seed } \\
\text { / capsule }\end{array}$ & $\begin{array}{r}\text { Total } \\
\text { seed } \\
\text { weight/ } \\
\text { capsule } \\
(\mathrm{g})\end{array}$ & $\begin{array}{r}\text { Dry } \\
\text { capsule } \\
\text { yield (kg/ } \\
\text { plot) }\end{array}$ & $\begin{array}{r}\text { Dry } \\
\text { capsule } \\
\text { yield } \\
\left(\mathrm{kg} \mathrm{ha}^{-1}\right)\end{array}$ & $\mathbf{r}_{\mathrm{g}}$ \\
\hline $\begin{array}{l}\text { No. of capsule bearing } \\
\text { sucker / plant }\end{array}$ & -0.481 & -0.058 & -0.147 & 0.034 & -0.006 & 0.154 & 1.061 & $0.571 * *$ \\
\hline No. of capsule/ plant & -0.159 & -0.175 & -0.359 & 0.031 & 0.012 & 0.152 & 1.130 & $0.640 * *$ \\
\hline Dry capsule weight (g) & -0.061 & -0.054 & -1.170 & 0.070 & 0.261 & 0.205 & 1.433 & $0.696 * *$ \\
\hline No. of seed/ capsule & -0.072 & -0.023 & -0.356 & 0.230 & 0.073 & 0.077 & 0.473 & $0.398 *$ \\
\hline $\begin{array}{l}\text { Total seed weight/ capsule } \\
\text { (g) }\end{array}$ & 0.008 & -0.006 & -0.794 & 0.044 & 0.385 & 0.137 & 0.776 & $0.559 * *$ \\
\hline $\begin{array}{l}\text { Dry capsule yield ( } \mathrm{kg} / \\
\text { plot) }\end{array}$ & -0.260 & -0.094 & -0.846 & 0.063 & 0.186 & 0.284 & 1.552 & $0.896 * *$ \\
\hline Dry capsule yield $\left(\mathrm{kg} \mathrm{ha}^{-1}\right)$ & -0.290 & -0.112 & -0.952 & 0.062 & 0.170 & 0.250 & 1.76 & $0.902 * *$ \\
\hline
\end{tabular}

Residual effect $=0.052$

$*$ and ** Significant at probability level of $0.05(\mathrm{r}=0.396)$ and 0.01 values $(\mathrm{r}=0.505)$, respectively, $\mathrm{r}_{\mathrm{g}}=$ genotypic correlation. 


\section{Phenotypic path analysis of pure seed yield with other characters}

The phenotypic direct and indirect effect of different characters on pure seed yield per plot is presented in Table 4. Dry capsule yield $\mathrm{kg} \mathrm{ha}^{-1}$ followed by total seed weight per capsule, dry capsule yield per plot and number of capsules per plant had exerted positive direct effect on pure seed yield. But number of capsule bearing sackers per plant and dry capsule weight had negative direct effect on pure seed yield at phenotypic level. Whereas, via dry capsule yield $\mathrm{kg} \mathrm{ha}^{-1}$ and dry capsule yield $\mathrm{kg}$ per plot showed considerable positive indirect effect on pure seed yield and the total correlation was significant and positive.

The current result clearly showed that the positive and significant correlation of number of capsule per plant, number of seed per capsule, total seed weight per plot, dry capsule yield per plot and dry capsule yield $\mathrm{kg} \mathrm{ha}^{-1}$ with pure seed yield per plot was due to the high direct effect of the characters. But the positive and significant phenotypic correlation of number of capsule bearing suckers per plant and dry capsule weight with pure seed yield per plot was due to the high and positive indirect effects of other characters via dry capsule yield per plot and dry capsule yield $\mathrm{kg} \mathrm{ha}^{-1}$. So direct selection based on high direct effect of the characters could be effective for increasing pure seed yield. Korikanthimath et al. (2000) in cardamom.

The path analysis showed the residual value of 0.014 which means the characters in the path analysis expressed the variability in seed yield by $98.6 \%$.

Table 4. Phenotypic direct effects (bold and diagonal) and indirect effects (off-diagonal) of different characters on seed yield in various korerima genotypes evaluated at Tepi

\begin{tabular}{|c|c|c|c|c|c|c|c|c|}
\hline Characters & $\begin{array}{r}\text { No. of } \\
\text { capsule } \\
\text { bearing } \\
\text { sucker/ plant }\end{array}$ & $\begin{array}{r}\text { No. of } \\
\text { capsule/ } \\
\text { plant }\end{array}$ & $\begin{array}{r}\text { Dry } \\
\text { capsule } \\
\text { weight } \\
(\mathrm{g})\end{array}$ & $\begin{array}{r}\text { No. of } \\
\text { seed/ } \\
\text { capsule }\end{array}$ & $\begin{array}{r}\text { Total seed } \\
\text { weight / } \\
\text { capsule }(g)\end{array}$ & $\begin{array}{r}\text { Dry } \\
\text { capsule } \\
\text { yield } \\
(\mathrm{kg} / \\
\text { plot }) \\
\end{array}$ & $\begin{array}{r}\text { Dry } \\
\text { capsule } \\
\text { yield }(\mathrm{kg} \\
\left.\mathrm{ha}^{-1}\right)\end{array}$ & $\mathrm{r}_{\mathrm{ph}}$ \\
\hline $\begin{array}{l}\text { No. of capsule bearing } \\
\text { sucker per plant }\end{array}$ & -0.146 & 0.047 & -0.147 & 0.043 & 0.071 & 0.163 & 0.602 & $0.628 * *$ \\
\hline No. of capsule per plant & -0.047 & 0.145 & -0.341 & 0.034 & 0.069 & 0.159 & 0.662 & $0.674 * *$ \\
\hline Dry capsule weight (g) & -0.034 & 0.078 & -0.637 & 0.036 & 0.313 & 0.219 & 0.786 & $0.754 * *$ \\
\hline No.of seed per capsule & -0.054 & 0.041 & -0.192 & 0.118 & 0.113 & 0.117 & 0.364 & $0.507 * *$ \\
\hline $\begin{array}{l}\text { Total seed weight/ capsule } \\
\text { (g) }\end{array}$ & -0.022 & 0.021 & -0.423 & 0.028 & 0.471 & 0.146 & 0.457 & $0.674 * *$ \\
\hline Dry capsule yield ( $\mathrm{kg} / \mathrm{plot})$ & -0.086 & 0.083 & -0.502 & 0.050 & 0.247 & 0.278 & 0.827 & $0.891 * *$ \\
\hline Dry capsule yield $\left(\mathrm{kg} \mathrm{ha}^{-1}\right)$ & -0.095 & 0.104 & -0.544 & 0.047 & 0.234 & 0.250 & 0.92 & $0.908 * *$ \\
\hline
\end{tabular}

Residual effect $=0.0142$

$*$ and ** Significant at probability level of $0.05(\mathrm{r}=0.396)$ and 0.01 values $(\mathrm{r}=0.505)$, respectively, $\mathrm{r}_{\mathrm{g}}=$ genotypic correlation

\section{Genotypic path analysis of dry capsule yield with other characters}

The genotypic direct and indirect effect of different characters on dry capsule yield $\mathrm{kg} \mathrm{ha}^{-1}$ is presented in Table 5. The maximum positive genotypic direct effect on dry capsule yield $\mathrm{kg} \mathrm{ha}^{-1}$ was exerted by dry capsule weight followed by number of capsule bearing sackers per plant, number of capsules per plant and dry capsule length, in contrast, number of seed per capsule, total seed weight per capsule and dry capsule yield per plot had negative direct effects on dry capsule yield at genotypic level.

The result indicated that the positive and significant correlation of dry capsule weight, number of capsule bearing suckers per plant, dry capsule length and number of capsule per plant with dry capsule yield $\mathrm{kg}^{\mathrm{h}} \mathrm{a}^{-1} \mathrm{was}$ due to the high direct effect of these characters. But the positive and significant genotypic correlation of number of seed per capsule, total seed weight per capsule and dry capsule yield per plot with dry capsule yield $\mathrm{kg} \mathrm{ha}^{-1}$ was due to the high and positive indirect effects of via dry capsule weight. So direct selection based on high direct effect of the characters could be effective for increasing dry capsule yield. It also suggested the possibility of indirect selection for high capsule yield via dry capsule weight could be effective for increasing dry capsule yield. Maximum positive direct effect of number of capsule bearing suckers per plant on dry capsule yield was also reported by Korikanthimath et al. (2000) in cardamom.

The residual effect was found 0.149 which means the characters in the path analysis expressed the variability in dry capsule yield by $85.1 \%$, indicated that there were other contributors which were responsible for capsule yield but not taken into consideration in the present investigation. 
Table 5. Genotypic direct effects (bold and diagonal) and indirect effects (off-diagonal) of different characters on seed yield in various korerima genotypes evaluated at Tepi

\begin{tabular}{|c|c|c|c|c|c|c|c|c|}
\hline Characters & $\begin{array}{r}\text { No. of } \\
\text { capsule } \\
\text { bearing } \\
\text { sucker / } \\
\text { plant }\end{array}$ & $\begin{array}{r}\text { No. of } \\
\text { capsul } \\
\text { e/ } \\
\text { plant }\end{array}$ & $\begin{array}{r}\text { Dry } \\
\text { capsul } \\
\mathrm{e} \\
\text { length } \\
(\mathrm{cm})\end{array}$ & $\begin{array}{r}\text { Dry } \\
\text { capsule } \\
\text { weight } \\
(\mathrm{g})\end{array}$ & $\begin{array}{r}\text { No. of } \\
\text { seed/ } \\
\text { capsule }\end{array}$ & $\begin{array}{r}\text { Total } \\
\text { seed } \\
\text { weight / } \\
\text { capsule } \\
(\mathrm{g})\end{array}$ & $\begin{array}{r}\text { Dry } \\
\text { capsule } \\
\text { Yield } \\
(\mathrm{kg} / \\
\text { plot })\end{array}$ & $\overrightarrow{r_{g}}$ \\
\hline No. of capsule bearing & & 0.073 & 0.000 & 0.085 & -0.011 & 0.0001 & -0.011 & $0.603 * *$ \\
\hline Sucker/ plant & 0.361 & & & & & & & \\
\hline No. of capsule/ plant & 0.119 & 0.222 & 0.002 & 0.208 & -0.010 & 0.0001 & -0.011 & $0.642 * *$ \\
\hline Dry capsule length $(\mathrm{cm})$ & 0.029 & 0.058 & 0.006 & 0.185 & -0.015 & 0.0001 & -0.006 & $0.378^{*}$ \\
\hline Dry capsule weight (g) & 0.045 & 0.068 & 0.002 & 0.677 & -0.022 & 0.0003 & -0.015 & $0.814 * *$ \\
\hline No. of seed per capsule & 0.054 & 0.030 & 0.001 & 0.206 & -0.074 & 0.0002 & -0.006 & $0.369 *$ \\
\hline $\begin{array}{l}\text { Total } \\
\text { weight/capsule (g) }\end{array}$ & -0.006 & 0.007 & 0.002 & 0.460 & -0.014 & -0.096 & -0.010 & $0.441 *$ \\
\hline $\begin{array}{l}\text { Dry capsule yield (kg/ } \\
\text { plot) }\end{array}$ & 0.195 & 0.119 & 0.002 & 0.489 & -0.020 & 0.0003 & -0.021 & $0.882 * *$ \\
\hline
\end{tabular}

Residual effect $=0.149$

$*$ and ** Significant at probability level of $0.05(\mathrm{r}=0.396)$ and 0.01 values $(\mathrm{r}=0.505)$, respectively, $\mathrm{r}_{\mathrm{g}}=$ genotypic correlation.

\section{Phenotypic path analysis of dry capsule yield with other characters}

The phenotypic direct and indirect effect of different characters on dry capsule yield is presented in Table 6 . Number of capsule bearing suckers per plant, number of capsule per plant, dry capsule weight and dry capsule yield per plot had exerted positive direct effect on dry capsule yield. But dry capsule length, number of seeds per capsule and total seed weight per plot had negative direct effect on dry capsule yield at phenotypic level. Whereas, via dry capsule weight showed considerable positive indirect effect on dry capsule yield and the total correlation were significant and positive. The result showed that the positive and significant correlation of number of capsule bearing sackers per plant, number of capsule per plant, dry capsule weight and dry capsule yield per plot with dry capsule yield was due to the high direct effect of these characters. But the positive and significant phenotypic correlation of dry capsule length, number of seed capsule and total seed weigh with dry capsule yield was due to the high and positive indirect effects of other characters via dry capsule weight. So direct selection based on high direct effect of the characters could be effective for increasing pure seed yield. Korikanthimath et al. (2000) in cardamom reported similar result. The residual effect was found 0.015 , which means the characters in the path analysis expressed the variability in dry capsule yield by $98.5 \%$., indicated that there were other contributors which was responsible for yield but not taken into consideration in the present investigation.

Table 6. Phenotypic direct effects (bold and diagonal) and indirect effects (off-diagonal) of different characters on seed yield in various korerima genotypes evaluated at Tepi

\begin{tabular}{|c|c|c|c|c|c|c|c|c|}
\hline Characters & $\begin{array}{r}\text { No. of } \\
\text { capsule } \\
\text { bearing } \\
\text { Sucker/ } \\
\text { plant }\end{array}$ & $\begin{array}{r}\text { No. of } \\
\text { capsule/ } \\
\text { plant }\end{array}$ & $\begin{array}{r}\text { Dry } \\
\text { capsule } \\
\text { length } \\
(\mathrm{cm})\end{array}$ & $\begin{array}{r}\text { Dry } \\
\text { capsu } \\
\text { le } \\
\text { weig } \\
\text { ht }(\mathrm{g})\end{array}$ & $\begin{array}{r}\text { No. of } \\
\text { seed/ } \\
\text { capsul } \\
\text { e }\end{array}$ & $\begin{array}{r}\text { Total } \\
\text { seed } \\
\text { weight } / \\
\text { capsule } \\
(\mathrm{g})\end{array}$ & $\begin{array}{r}\text { Dry } \\
\text { capsul } \\
\text { e yield } \\
(\mathrm{kg} / \mathrm{plo} \\
\mathrm{t})\end{array}$ & $\mathrm{r}_{\mathrm{ph}}$ \\
\hline No. of capsule bearing & & 0.075 & -0.003 & 0.138 & -0.011 & -0.005 & 0.056 & $0.654 * *$ \\
\hline Sucker/plant & 0.397 & & & & & & & \\
\hline No. of capsule/plant & 0.129 & 0.231 & -0.009 & 0.319 & -0.008 & -0.004 & 0.054 & $0.720 * *$ \\
\hline Dry capsule length $(\mathrm{cm})$ & 0.051 & 0.087 & -0.024 & 0.272 & -0.002 & -0.013 & 0.042 & $0.420 *$ \\
\hline Dry capsule weight (g) & 0.092 & 0.124 & -0.011 & 0.597 & -0.009 & -0.020 & 0.075 & $0.854 * *$ \\
\hline No. of seed per capsule & 0.146 & 0.066 & -0.001 & 0.180 & -0.029 & -0.007 & 0.040 & $0.396 *$ \\
\hline $\begin{array}{l}\text { Total seed weight/capsule } \\
\text { (g) }\end{array}$ & 0.060 & 0.034 & -0.010 & 0.396 & -0.007 & -0.030 & 0.050 & $0.497 *$ \\
\hline Dry capsule yield (kg/plot) & 0.233 & 0.132 & -0.011 & 0.470 & -0.012 & -0.016 & 0.095 & $0.899 * *$ \\
\hline
\end{tabular}

Residual effect $=0.015$

$*$ and ** Significant at probability level of $0.05(\mathrm{r}=0.396)$ and 0.01 values $(\mathrm{r}=0.505)$, respectively, $\mathrm{r}_{\mathrm{g}}=$ genotypic correlation 


\section{Conclusion}

Based on the findings of the present investigation the following conclusion could be made; the correlation coefficients of quantitative characters and partitioning of genotypic correlation to pure seed revealed positive and significant correlation both at genotypic and phenotypic levels with number of capsule bearing suckers per plant, number of capsules per plant, dry capsules weight, number of seeds per capsule, total seeds weight per capsule, dry capsule yield per plot and dry capsule yield ha- ${ }^{-1}$. Number of seeds per capsule, total seed weight per plot, dry capsule yield per plot and dry capsule yield had high and positive direct effects on pure seed yield, however, number of capsule bearing sackers per plant, dry capsule weight and number of capsule per plant had negative direct effects on pure seed yield at genotypic level.

\section{Acknowledgement}

We would like to thanks Teppi National Spice Research Center (TNSRC) and Technology Multiplication and Seed Research Directorate ,EIAR, for the financial and unreserved moral support during research work. Finally we would like to thank the publishers as well.

\section{Reference}

Dabholkar, A.R. 1992. Elements of Biometrical Genetics. Shock Kumar Mittal Concept publishing company. New Delhi, India. 213p.

Dewey, D. R. and K.H. Lu. 1959. A Correlation and path coefficient analysis of components of crested wheat grass production. Agron. J. 52: 515-518.

Eyob Seyifu, 2009. Promotion of seed germination, subsequent seedling growth and in vitro propagation of korarima (Aframomum corrorima (Braun) P.C. M. Jansen). Journal of Medicinal Plant Resources, 3: 652659.

Eyob Seyifu, Martinsen, B.K., Tsegaye, A., Appelgren, M. and Skrede, G. 2008. Antioxidant and antimicrobial activities of extract and essential oil of korarima (Aframomum corrorima (Braun) P.C.M. Jansen). Africa Journal Biotechnology, 7: 2585-2592.

Karim, D., Sarkar, U., Siddique, M.N.A., Khaleque Miah, M. A. and Hasnat, M. Z. 2007. Variability and Genetic Parameter Analysis in Aromatic Rice. Int. J. Sustain. Crop Prod. 2(5):15-18.

Kassahun Tesema. 2006. Variability and association among bulb yield and related characters in garlic (Allium sativum L.). An M.Sc Thesis, Haramaya University, Haramaya, Ethiopia.

Korikanthimath, V.S.D., Prasath, A.A., Mohamed sayed. 2000. Association of yield attribute Among quantitative character of cardamom (Elettaria cardamom maton). Journal of spice and aromatic crops, $2: 155-156$.

Panse, V. G. 1957. Genetics of quantitative characters in relation to plant breeding. Indian J. Gent. 17: 318-328.

Robertson,A.1959. The sampling variance of the genetic correlation coefficient. Biometrics, 15:469-485.

Sharma, J.R. 1998. Statistical and Biometrical Techniques in Plant Breeding. New age international publishers, New Delhi.432p.

Surawit, W. and Wondyifraw Tefera. 2013. In Vitro Chromosome Doubling in Korarima [Aframomum corrorima (Braun) P.C.M. Jansen] Using Colchicine and Oryzalin. Asetsart J. (Nat. Sci.) 47 : 684 - 694.

TNSRC (Tepi National Spices Research Centre). 2015. National research strategy for spices plants. Tepi, Ethiopia. Ethiopia.

Tukey, J. W. 1954. Causation, segregation and path analysis of causal path. Biometrics. 15: 236-258.

Tukey, J. W. 1954. Causation, segregation and path analysis of causal path. Biometrics. 15: 236-258.

Wright, S. 1921. Correlation and Causation. J. Agric. Res. 20: 557-587. 